\title{
Why does Jack, and not Jill, break his crown? Sex disparity in brain tumors
}

Tao Sun, Nicole M Warrington and Joshua B Rubin ${ }^{*}$

\begin{abstract}
It is often reported that brain tumors occur more frequently in males, and that males suffer a worse outcome from brain tumors than females. If correct, these observations suggest that sex plays a fundamental role in brain tumor biology. The following review of the literature regarding primary and metastatic brain tumors, reveals that brain tumors do occur more frequently in males compared to females regardless of age, tumor histology, or region of the world. Sexually dimorphic mechanisms that might control tumor cell biology, as well as immune and brain microenvironmental responses to cancer, are explored as the basis for this sex disparity. Elucidating the mechanisms by which sex chromosomes and sex hormones impact on brain tumorigenesis and progression will advance our understanding of basic cancer biology and is likely to be essential for optimizing the care of brain tumor patients.
\end{abstract}

Keywords: sex, brain tumors, brain metastases, sexually dimorphic signaling, cytokines

\section{Review}

Primary brain tumors, including both malignant (highgrade) and benign (low-grade) tumors, are highly morbid and life-threatening diseases, particularly as a function of tumor histology, tumor location, and patient age [1-4]. For many common brain tumors, outcome has not improved significantly over the past 25 years despite enormous advancements in neuroimaging, neurosurgery, molecular diagnostics and chemotherapy [5]. Thus, much of current research focuses on those aspects of tumor cell biology and patient characteristics that drive tumorigenesis and resistance to therapy. In this regard, the greater prevalence of primary and metastatic brain tumors in males compared to females, regardless of age, tumor histology and region of the world, strongly suggests that sex is an important determinant of brain tumor biology. Further evaluation of the molecular mechanisms by which sex affects brain tumorigenesis could have significant impact on our understanding of tumorigenesis in the brain and our approaches to treatment of males and females with brain tumors. In the following, we review the epidemiology of parenchymal

\footnotetext{
* Correspondence: rubin_j@kids.wustl.edu Department of Pediatrics, Division of Pediatric Hematology-Oncology, Washington University School of Medicine, CB 8208, 660 South Euclid Ave,
} St Louis, MO 63110, USA brain tumors with an emphasis on the relationship between sex and brain tumor incidence, and explore sexually dimorphic mechanisms that could potentially underlie this critical element of brain tumor biology.

\section{Primary brain tumors occur more commonly in males throughout the world}

Cancer rates often exhibit geographical variation suggestive of racial and environmental influences on tumorigenesis [6-9]. To determine whether similar regional and racial factors influence how sex correlates with brain tumor incidence, we retrospectively reviewed 16 independent reports in which data regarding sex and brain tumor histology was readily available [2,10-24]. A clear predominance of brain tumors in males was evident in reports from 15 different countries on 6 continents in which the ratio of cases in males compared to females ranged from $>1$ to 3.5 for the major histological subtypes of central nervous system (CNS) parenchymal diseases including astrocytoma (AST), glioblastoma multiforme (GBM), medulloblastoma (MB), ependymoma (EPD) and oligodendroglioma (OLG) (Figure 1). These observations indicate that sex affects brain tumorigenesis through mechanisms that are likely to be independent of race and regional differences in environmental exposures. 


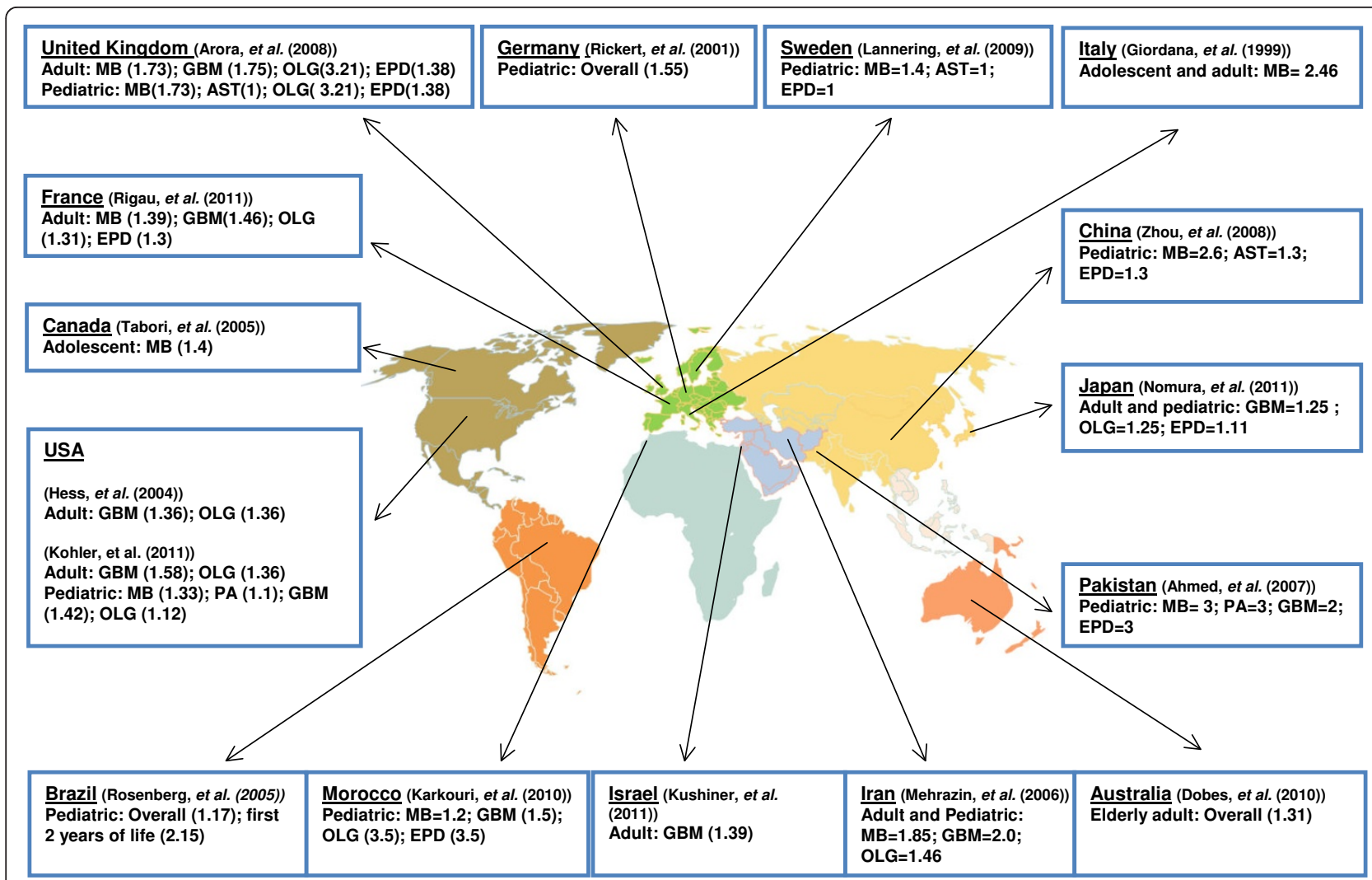

Figure 1 Sex-based differences in the rates of primary brain tumor exist regardless of age or geographical location. Reports from around the world describing the incidence of common brain tumors as a function of sex are identified and linked to their countries of origin. Numbers shown in the parentheses are the sex ratio (male/female) of major primary brain tumor types extracted from 16 independent publications from 15 countries, including all major continents and regions of the world (North America, South America, Europe, Middle East, Africa, Asia and Oceania) except for Antarctica. Overall, these studies covered the period of 1974 to 2008, and the sex ratio (male/female) in almost all major brain tumors including both malignant and benign tumors is greater than 1 with a range of 1 to approximately 3.5. See also [2,10-24]. Abbreviations: AST = astrocytoma; EPD = ependymoma; GBM = glioblastoma (multiforme); Glioma, (NOS) = glioma, not otherwise specified; $\mathrm{MB}$ = medulloblastoma; $\mathrm{OLG}=$ oligodendroglioma; $\mathrm{PA}$ = pilocytic astrocytoma.

In contrast to the above, meningiomas are intracranial tumors that occur more commonly in females than males [25]. However, meningioma is a mesenchymal tumor and not a tumor of the brain parenchyma. Instead, it derives and is generally confined to the meningeal membranes that cover the brain. While the sex disparity in meningioma is fascinating and no doubt important, the extra-axial nature of meningioma separates it from the parenchymal brain tumors described above and it will not be discussed further in this review.

\section{Primary brain tumors occur more commonly in males regardless of age}

For some cancers, the actions of sex hormones can promote or suppress tumor progression. For example, estrogens can promote receptor positive breast cancer development [26] but reduce the risk of gastric cancer [27]. Analysis of brain tumor rates in older men and postmenopausal women, as well as in prepubertal children suggests that sex-dependent differences in circulating sex steroids alone cannot account for the disparity in brain tumor rates in men and women. In Israel and Australia, brain tumors occur more frequently in males older than 65 than in postmenopausal women $(\mathrm{M} / \mathrm{F}$ ratio $=1.3)[16,18]$. In Los Angeles County, California, the overall GBM incidence increased in both sexes between 1974 and 1999. A male predominance in brain tumors was evident throughout this period, and this sex disparity dramatically increased in individuals older than 65 [28].

Brain tumors are the leading cause of cancer-related mortality in children [29]. Childhood brain tumors and adult brain tumors differ in many ways including intracranial locations, histological subtypes, presentation and outcome [30-34]. Even for the same histological subtypes, children and adults can exhibit distinct molecular foundations. For instance, medulloblastoma, the most common malignant brain tumor of childhood, develops 
infrequently in adults and exhibits age-dependent molecular signatures [35,36]. Similarly, GBM occurs in infants, teenagers and adults with distinct molecular mechanisms and outcomes $[37,38]$. Despite divergent pathogenesis, male predominance in medulloblastoma and GBM exists in both adult and pediatric populations, even in individuals of less than 2 years [14] (Figure 1). Thus, the influence of sex on brain tumorigenesis is operative regardless of age and sexual maturity, suggesting that it is not a consequence of the acute effects of circulating sex hormones.

\section{Secondary brain tumors (metastases) occur more} commonly in males regardless of the primary cancer type As many as one-third of all adult cancer cases are complicated by metastases to the brain [39-41]. Brain metastases occur most frequently in lung cancer $(48 \%)$ and breast cancer (16.5\%) followed by a spectrum of other cancers including melanoma, at frequencies less than $10 \%$ [40]. A striking disparity in the rates of brain metastases in male and female cancer patients is evident in several large studies involving different primary cancers (Table 1). While rates of primary lung cancer are nearly equivalent in men and women in the US (54\% male, (http://www.cdc.gov/cancer/lung/statistics/[42]), between $58 \%$ and $83 \%$ of all lung-derived brain metastases occur in male patients [43-47]. Similarly, the rates of melanoma are higher among women (http://www.cdc. gov/cancer/dcpc/research/articles/melanoma_supplement.htm, [42]), yet between $58 \%$ and $64 \%$ of all melanoma-derived brain metastases occur in male patients [48-50]. The sex disparity in brain metastases is evident in tumors derived from different tissues, including those arising from different germ layers such as lung cancer (endoderm and mesodermal origins) and melanoma (neuroectodermal origin), suggesting that it may involve differences in non-cell autonomous effects on cancer cell biology including sexual dimorphism in immune function and the microenvironment of the male and female brains.

While the frequency of brain metastases complicating pediatric cancers is far less than in adult cancers, a male-female difference is evident in germ cell tumor (GCT) metastases to the brain with $13 / 15$ reported cases occurring in males [51]. This is particularly interesting given the large disparity in the rates of primary intracranial GCT in young boys and girls. While the reported overall ratio for GCTs (germinoma and non-

Table 1 Sex dependent pattern of brain metastases (BM)

\begin{tabular}{|c|c|c|c|c|}
\hline Study (year) & Total BM & BM (lung cancer) & BM (melanoma) & Survival \\
\hline \multicolumn{5}{|c|}{ Lagerwaard et al. (1999): } \\
\hline Male & $810(75 \%)$ & 601 (83\%) & & \\
\hline Female & $269 *(25 \%)$ & $120(17 \%)$ & & \\
\hline \multicolumn{5}{|c|}{ Chao et al. (2006): } \\
\hline Male & $687(61 \%)$ & & & 5.8 months \\
\hline Female & $443 *(39 \%)$ & & & 6.1 months \\
\hline \multicolumn{5}{|c|}{ Videtic et al. (2009): } \\
\hline Male & & 487 (58\%) & & 5.5 months \\
\hline Female & & $348(42 \%)$ & & 6.3 months \\
\hline \multicolumn{5}{|c|}{ Arrieta et al. (2009): } \\
\hline Male & & $164(56 \%)$ & & \\
\hline Female & & 129 (44\%) & & \\
\hline \multicolumn{5}{|c|}{ Assouline et al. (2011): } \\
\hline Male & $164(78 \%)$ & & & \\
\hline Female & $45^{*}(22 \%)$ & & & \\
\hline \multicolumn{5}{|c|}{ Sampson et al. (1998): } \\
\hline Male & & & $431(64 \%)$ & \\
\hline Female & & & $239(36 \%)$ & \\
\hline \multicolumn{5}{|c|}{ Hofmann et al. (2007): } \\
\hline Male & & & 77 (58\%) & 17 weeks \\
\hline Female & & & $56(42 \%)$ & 36 weeks \\
\hline \multicolumn{5}{|c|}{ Raizer et al. (2008): } \\
\hline Male & & & $217(61 \%)$ & \\
\hline Female & & & $138(39 \%)$ & \\
\hline
\end{tabular}

*The following number of breast cancer cases was subtracted from the total number of female brain metastasis cases: Lagerwaard (213), Chao (158), Assouline (23). 
germinomatous tumors) in boys compared to girls ranges from approximately 3 to as much as 13:1, [52-54], regional variation within the brain is evident. In all, $70 \%$ of male GCTs occur in the pineal region and $75 \%$ of female GCTs occur in the suprasellar region [55-57]. Within the pineal region male tumors predominate, but in the suprasellar region the ratio of male to female GCTs is more equivalent. The patterns of primary and metastatic CNS GCTs suggest that critical sex and region-dependent interactions occur between GCTs and the brain microenvironment.

\section{Sexually dimorphic biology may underlie sex disparity in brain tumors}

Primary and metastatic brain tumors occur more frequently in males compared to females regardless of tumor type, age, race or region of the world. These observations suggest the existence of sexually dimorphic mechanisms that broadly impact on tumorigenesis and tumor progression. In this section we will examine sexual dimorphism in pathways that could regulate cancer growth and metastasis.

At birth, the brains of human males are $7.8 \%$ larger than those of females. The sex disparity in brain size is maintained and increases throughout life, such that the average adult male brain is approximately $11 \%$ larger than the female brain $[58,59]$. These disparities are not a consequence of the acute actions of circulating sex hormones alone, and are instead the result of components of sexual differentiation that are measureable from the time of fertilization. By 2 days post fertilization, male embryos have more cells than female embryos $[59,60]$. This is well before gonadal differentiation at 8 weeks, and indicates that sex chromosome-based mechanisms of growth regulation exist [60]. Among the genes encoded on the $\times$ chromosome that could directly impact growth are glucose- 6 phosphate dehydrogenase (G6PD), hypoxanthine phosphoribosyltransferase 1 (HPRT1) and X-linked inhibitor of apoptosis protein (XIAP) [61]. By the blastocyst stage of human development, measureable differences in the expression of these proteins as well as in the autosomally encoded DNA methyltransferases DNMT3 A and B are evident. Thus, at the preimplantation stage of embryogenesis, significant differences in both sex chromosome encoded gene expression and in more global gene expression are observed between male and female embryos [62-65].

In addition to differences in gene expression, male and female embryos exhibit differences in physiology. Total glucose metabolism in human male embryos is twice that of females and male embryos exhibit higher pyruvate and glucose uptake and lactate production than female embryos $[62,63,66,67]$. Female embryos exhibit greater G6PD expression and activity and four times the pentose phosphate pathway (PPP) activity as observed in males $[62,63,66,68]$. Alterations in glucose metabolism are required for cancerous growth, and glucose must be shunted from energy production to biosynthetic pathways $[69,70]$. Cancer cells preferentially employ aerobic glycolysis (the Warburg effect), a non-oxidative form of glucose metabolism characterized by increased glucose utilization and lactate production [71-73]. Whether differences in glucose consumption, lactate production, G6PD and PPP activity in males and females renders them more or less susceptible to oncogenic transformation remains to be determined.

Abnormal activation of the mitogen-activated protein kinase (MAPK) pathway is a common mechanism for dysregulated proliferation and survival in astrocytomas and other cancers [74]. Greater MAPK pathway activation has been observed in male smooth muscle cells in vitro [75] as well as in multiple areas of the male brain in vivo [76,77]. Estrogens suppress MAPK activity in a sexdependent manner. In vitro, basal levels of activated (phosphorylated) MAPK and extracellular-regulated kinase (ERK) $1 / 2$ were higher in female compared to male astrocytes. However, female astrocytes exhibited greater sensitivity to the MAPK pathway inhibitory effects of estradiol than did male astrocytes $[78,79]$. Differential sensitivity to the inhibitory effects of MAPK regulation by estrogens was correlated with downstream processes such as proliferation and apoptosis. Furthermore, estrogen treatment increased apoptosis in female cells to a greater degree than in male cells and decreased the percentage of female, but not male, cells in $\mathrm{S}$ phase of the cell cycle $[78,79]$. In the brain, estradiol is produced from testosterone through the actions of aromatase. Aromatase expression is greater in female compared to male astrocytes rendering female astrocytes more sensitive to the effects of testosterone/estradiol than male astrocytes [80]. Interestingly, in an intracranial xenograft model of GBM, estradiol was determined to induce tumor cell apoptosis and promote survival [81].

Among the important targets for estrogen regulation of growth is the cyclic AMP responsive element binding protein (CREB). CREB is a transcription factor that integrates the growth promoting signals downstream of multiple intracellular pathways such as the MAPK, p38MAPK, phosphatidylinositol-3-kinase (PI3K)-AKT and cyclic AMP (cAMP) pathways [82]. Estradiol promotes CREB phosphorylation and interaction with cAMP response elements within the promoter regions of CREB target genes. The action of testosterone-derived estradiol results in higher levels of phospho-CREB in male astrocytes on the day of birth in sexually dimorphic areas of the brain [78]. In addition, the expression of several growth factors including transforming growth factor (TGF) $\beta 2$ is directly regulated by 


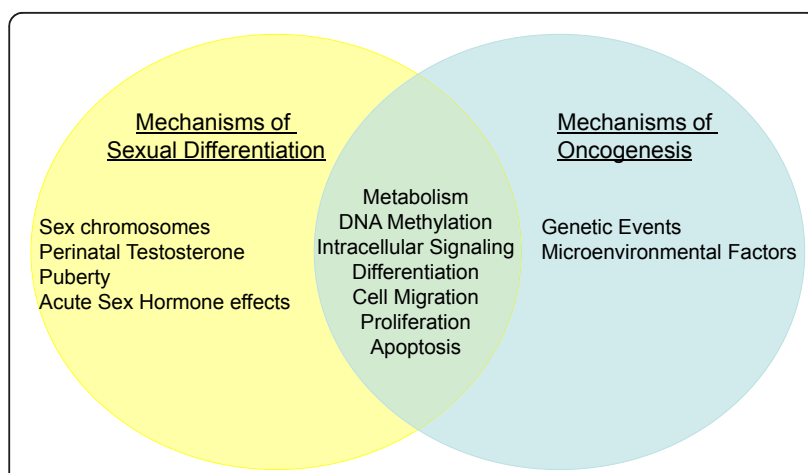

Figure 2 The mechanisms of sexual differentiation overlap with the mechanisms of oncogenesis. The process of sexual differentiation shares many fundamental features with oncogenesis, including changes in DNA methylation, glucose metabolism, growth factor signaling, cell migration, proliferation, apoptosis and differentiation.

estradiol in astrocytes [78]. Importantly, TGF $\beta 2$ is frequently elevated in cancer cells [83]. Thus, the mechanisms of sexual differentiation share many similarities with the mechanisms of oncogenesis (Figure 2). How the process of sexual differentiation and sexually dimorphic regulation of cellular growth relates to cancer biology should be more fully explored.

\section{Mechanisms of brain metastases}

As first suggested by Paget [84] and demonstrated by Hart and Fidler [85], patterns of solid tumor metastases reflect both tumor cell intrinsic and target tissue microenvironmental factors [86]. In this regard the prevalence of metastases to the brain in male cancer patients is relevant to this discussion.

Current models of metastasis describe a multistage process in which primary tumor cells first gain access to the lymphatics or circulatory system through mechanisms that resemble the normal epithelial to mesenchymal transitions (EMT) that accompany the movement of epithelial cells through the germ layers during early development [87]. An EMT-like phenomenon, including degradation of extracellular matrix and activation of migratory pathways is also observed in cancer, and appears to be essential for metastases [88]. Subsequent establishment of secondary tumors involves avoidance of negative and engagement of positive interactions with the immune system [89], adhesion within target tissues and growth of metastatic lesions through a series of reciprocal interactions between disseminated tumor cells and the microenvironment of target tissues [90,91] (Figure 3).

Each stage of tumor metastasis involves mechanisms that might function in a sexually dimorphic fashion and

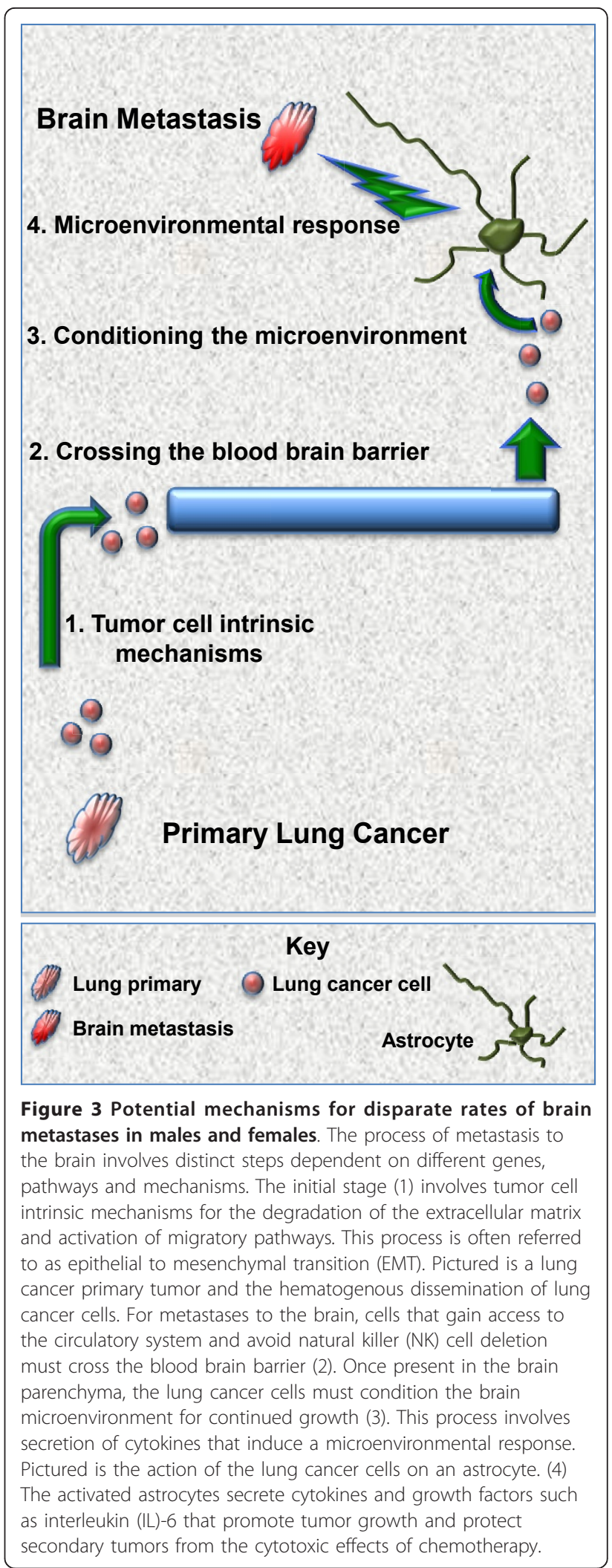


thereby contribute to the disparate rates of brain metastases observed in multiple cancers. In non-small cell lung cancer, periostin expression, a marker of EMT, was significantly correlated with being male, suggesting that males might possess greater tumor cell intrinsic potential for metastasis [92].

While activation of innate immune cells may promote metastases, it is also likely that prior to the establishment of secondary tumors, tumor cells are vulnerable to immune surveillance and destruction. There are data to suggest that natural killer (NK) cells play an especially important role in this antimetastatic function [93]. NK cell activity displays differential sensitivity to adrenergic suppression in male and female rats, and this increases the susceptibility of male rats to experimental lung metastases. In a lung retention model of intravenously introduced breast carcinoma cells (MADB106), male rats displayed a greater sensitivity to metoproterenol induced $\beta$ adrenergic activation than female rats [94]. Prior to sexual maturation, differential sensitivity to metoproterenol was not apparent. Further, ovariectomy of female rats had no effect, while castration of male rats abolished the metoproterenol effect in adult animals. These data suggest that sexually dimorphic immune surveillance may impact on tumor metastases in a circulating testosterone-dependent manner.

NK cell function and other components of the peripheral immune response may have limited impact on the behavior of tumor cells once they gain access to the CNS parenchyma. Instead, astrocytes and resident microglia are the predominant components of the CNS cellular immune response. Brain metastases are correlated with significant astrocytic inflammatory reaction in the brain. In response to inflammatory stimuli, astrocytes become 'activated' and in this state secrete a number of cytokines with potential growth promoting properties including interleukin (IL)-1 $\beta$, IL-3, IL-6, tumor necrosis factor (TNF) $\alpha$, TGF $\beta$, insulin-like growth factor (IGF)-1 and platelet-derived growth factor (PDGF) [95]. In experiments designed to identify astrocyte-derived factors essential for metastasis growth, IL$1 \beta$, IL- 6 and TNF $\alpha$ were all found to be capable of stimulating HARA-B lung carcinoma growth [96]. Similarly, coculture of astrocytes with lung or breast cancer cells resulted in the upregulation of survival genes in the cancer cells and the promotion of chemoresistance [97]. Microenvironment-derived interleukin promotion of tumor growth has also been seen with IL- $1 \beta$ stimulation of melanoma [98-100] and IL-6 promotion of primary colon cancer and liver cancers $[101,102]$.

The broad importance of cytokines, especially IL-1 and IL-6 to tumor growth is relevant to sex disparity in brain metastases because astrocyte production of cytokines is sexually dimorphic. While baseline expression of IL-1 $\beta$, IL-6, interferon-inducible protein (IP)-10 and TNF $\alpha$ was similar in male and female astrocytes, a significant disparity became apparent upon stimulation with lipopolysaccharide (LPS). Under these infection mimetic conditions, expression of IL-1 $\beta$, IL- 6 and TNF $\alpha$ was significantly greater in male versus female astrocytes [103]. Testosterone treatment of neonatal female mice produced a male pattern of cytokine response in adult animals suggesting that sexually dimorphic cytokine production by astrocytes is a stable difference in function that is dependent upon the perinatal surge in testosterone. Similar disparity was observed in liver and colon production of cytokines during primary tumorigenesis of carcinoma [101,102]. In this case, the effects of sex appeared to be mediated by the inhibitory effects of estrogen on IL- 6 signaling rather than testosterone dependent sensitivity to immune suppression.

Further evidence for estrogen effects on tumor progression come from the study of sex on tumorigenesis in a mouse model of medulloblastoma genesis as a consequence of mutation in the sonic hedgehog ( $\mathrm{SHH})$ receptor patched (PTC). In this model, more than 50\% of Ptc heterozygous mice develop preneoplastic lesions, but bona fide malignancies develop in only $14 \%$ to $20 \%$ [104,105]. Ovariectomized Ptc \pm mice exhibited a higher rate of tumor progression while estrogen treatment of ovariectomized mice returned the tumor rate to baseline [106]. In this case, the genesis of medulloblastoma is driven by $\mathrm{SHH}$ pathway activation. Estrogen did not alter the level of SHH pathway activation. This suggests that estrogen might not exert its effect directly on medulloblastoma cells, but rather might influence microenvironmental function. This interpretation is supported by epidemiological data that suggests $\mathrm{SHH}$-driven medulloblastoma do not occur at different rates in prepubertal boys and girls [107]. Testing this hypothesis would require examining the effects of sex and estrogen on the promotion of $\mathrm{SHH}$-independent tumor types.

Tumor recruitment and activation of astrocytes may not only be important for the formation of metastases, but also in the relative resistance of metastases to therapy. In a model of experimental melanoma metastases, astrocytes protected melanoma cells from the cytotoxic effects of both p-glycoprotein sensitive and insensitive agents [108]. The protection required direct contact between tumor cells and astrocytes, gap junction communication and appeared to be calcium dependent.

Thus, the disparate rates of brain metastases in males and females appear to be a consequence of sexually dimorphic tumor cell intrinsic mechanisms, as well as disparity in immune cell and astrocyte function. Defining the sex-dependent mechanisms that regulate brain metastases could advance efforts to (i) identify patients at the highest risk for metastatic disease, (ii) prevent 
metastases from occurring, and (iii) improve brain metastasis treatments.

\section{Sex impacts on outcome from primary and secondary brain tumors}

The influence of sex on brain tumors extends beyond tumorigenesis and includes outcome. It has been demonstrated in both pediatric and adolescent groups that males with medulloblastomas have a worse prognosis than females $[12,109,110]$. Similarly females with either low-grade or high-grade gliomas exhibit higher survival compared to males [111-113]. The survival advantage of being female also extends to brain metastases where women with either lung cancer primaries or melanoma exhibit longer survival compared to men with the same condition $[44,46,50]$.

\section{Conclusions}

The current failure of neuro-oncology to cure more children and adults with brain tumors demands continued effort to understand the molecular basis for brain tumorigenesis and to apply this knowledge to the prevention and treatment of brain tumors. In this regard, the significant impact that sex has on brain tumor incidence and outcome suggests that important oncogenic mechanisms will be revealed through the illumination of how sex affects brain tumorigenesis. It is likely that this will involve cell intrinsic mechanisms regulating metabolism and growth, as well as fundamental mechanisms of cell migration, invasion, immune activity and crosstalk between tumor cells and their microenvironment. At the very least, these efforts should help reduce the rates of brain tumors in males to those in females and improve the outcome for males to equal that of females. Beyond that, one can hope that understanding sex disparity in brain tumors is so fundamental to tumor biology that it will ultimately result in reduced rates of brain tumors and improved outcome for everyone.

\section{Acknowledgements}

This work was supported by grant RO1 CA CA118389 (JBR).

\section{Authors' contributions}

TS, NMW and JBR each contributed to the literature review and the writing of this manuscript. All authors read and approved the final manuscript.

\footnotetext{
Authors' information

JBR is the Co-Director of Pediatric Neuro-Oncology at St Louis Children's Hospital and the Co-Leader of the Cancer and Developmental Biology Program at The Siteman Cancer Center, Washington University School of Medicine. JBR's laboratory research is focused on the mechanisms of brain tumorigenesis in childhood.
}

\section{Competing interests}

JBR has a patent application pending to use a SNP-based predictor of astrocytoma risk in neurofibromatosis 1 that incorporates the effects of sex.
Received: 25 November 2011 Accepted: 25 January 2012

Published: 25 January 2012

\section{References}

1. Barnholtz-Sloan JS, Sloan AE, Schwartz AG: Relative survival rates and patterns of diagnosis analyzed by time period for individuals with primary malignant brain tumor, 1973-1997. J Neurosurg 2003, 99:458-466.

2. Kohler BA, Ward E, McCarthy BJ, Schymura MJ, Ries LA, Eheman C, Jemal A, Anderson RN, Ajani UA, Edwards BK: Annual report to the nation on the status of cancer, 1975-2007, featuring tumors of the brain and other nervous system. J Natl Cancer Inst 2011, 103:714-736.

3. Surawicz TS, Davis F, Freels S, Laws ER, Menck HR: Brain tumor survival: results from the National Cancer Data Base. J Neurooncol 1998, 40:151-160.

4. Pollack IF: Multidisciplinary management of childhood brain tumors: a review of outcomes, recent advances, and challenges. J Neurosurg Pediatr 8:135-148.

5. Abdullah S, Qaddoumi I, Bouffet E: Advances in the management of pediatric central nervous system tumors. Ann N Y Acad Sci 2008, 1138:22-31

6. O'Sullivan EM: International variation in the incidence of oral and pharyngeal cancer. Community Dent Health 2008, 25:148-153.

7. Pisani P: Breast cancer: geographic variation and risk factors. J Environ Pathol Toxicol Oncol 1992, 11:313-316.

8. Stiller CA, Parkin DM: International variations in the incidence of childhood renal tumours. Br J Cancer 1990, 62:1026-1030.

9. Kheirandish P, Chinegwundoh F: Ethnic differences in prostate cancer. $\mathrm{Br} J$ Cancer 105:481-485.

10. Arora RS, Alston RD, Eden TO, Estlin EJ, Moran A, Birch JM: Age-incidence patterns of primary CNS tumors in children, adolescents, and adults in England. Neuro Oncol 2009, 11:403-413.

11. Rigau V, Zouaoui S, Mathieu-Daudé H, Darlix A, Maran A, Trétarre B, Bessaoud F, Bauchet F, Attaoua R, Fabbro-Peray P, Fabbro M, Kerr C, Taillandier L, Duffau H, Figarella-Branger D, Costes V, Bauchet L, Société Française de Neuropathologie (SFNP), Société Française de Neurochirurgie (SFNC), Club de Neuro-Oncologie of the Société Française de Neurochirurgie (CNO-SFNC), Association des Neuro-Oncologues d'Expression Française (ANOCEF): French Brain Tumor Database: 5-year histological results on 25756 cases. Brain Pathol 2011, 21:633-644.

12. Tabori U, Sung L, Hukin J, Laperriere N, Crooks B, Carret AS, Silva M, Odame I, Mpofu C, Strother D, Wilson B, Samson Y, Bouffet E, Canadian Pediatric Brain Tumor Consortium: Distinctive clinical course and pattern of relapse in adolescents with medulloblastoma. Int J Radiat Oncol Biol Phys 2006, 64:402-407.

13. Hess KR, Broglio KR, Bondy ML: Adult glioma incidence trends in the United States, 1977-2000. Cancer 2004, 101:2293-2299.

14. Rosemberg S, Fujiwara D: Epidemiology of pediatric tumors of the nervous system according to the WHO 2000 classification: a report of 1,195 cases from a single institution. Childs Nerv Syst 2005, 21:940-944.

15. Karkouri M, Zafad S, Khattab M, Benjaafar N, El Kacemi H, Sefiani S, Kettani F, Dey S, Soliman AS: Epidemiologic profile of pediatric brain tumors in Morocco. Childs Nerv Syst 2010, 26:1021-1027.

16. Kushnir I, Tzuk-Shina T: Efficacy of treatment for glioblastoma multiforme in elderly patients (65+): a retrospective analysis. Isr Med Assoc J 2011, 13:290-294

17. Mehrazin $M$, Rahmat $H$, Yavari P: Epidemiology of primary intracranial tumors in Iran, 1978-2003. Asian Pac J Cancer Prev 2006, 7:283-288,

18. Dobes M, Shadbolt B, Khurana VG, Jain S, Smith SF, Smee R, Dexter M, Cook R: A multicenter study of primary brain tumor incidence in Australia (2000-2008). Neuro Oncol 2011, 13:783-790.

19. Ahmed N, Bhurgri Y, Sadiq S, Shakoor KA: Pediatric brain tumours at a tertiary care hospital in Karachi. Asian Pac J Cancer Prev 2007, 8:399-404.

20. Nomura E, loka A, Tsukuma H: Trends in the incidence of primary intracranial tumors in Osaka, Japan. Jpn J Clin Oncol 2011, 41:291-294.

21. Zhou D, Zhang Y, Liu H, Luo S, Luo L, Dai K: Epidemiology of nervous system tumors in children: a survey of 1,485 cases in Beijing Tiantan Hospital from 2001 to 2005. Pediatr Neurosurg 2008, 44:97-103.

22. Giordana MT, Schiffer P, Lanotte M, Girardi P, Chio A: Epidemiology of adult medulloblastoma. Int J Cancer 1999, 80:689-692.

23. Lannering B, Sandstrom PE, Holm S, Lundgren J, Pfeifer S, Samuelsson U, Stromberg B, Gustafsson G: Classification, incidence and survival analyses 
of children with CNS tumours diagnosed in Sweden 1984-2005. Acta Paediatr 2009, 98:1620-1627.

24. Rickert $\mathrm{CH}$, Paulus W: Epidemiology of central nervous system tumors in childhood and adolescence based on the new WHO classification. Childs Nerv Syst 2001, 17:503-511.

25. Perry A, Louis DN, Scheithauer BW, Budka H, von Deimling A: Meningioma. In WHO Classification of Tumours of the Nervous System. Edited by: Louis DN, Ohgaki H, Wiestler OD, Cavenee WK. Lyon, France: WHO Press; 2007:164-172.

26. Platet N, Cathiard AM, Gleizes M, Garcia M: Estrogens and their receptors in breast cancer progression: a dual role in cancer proliferation and invasion. Crit Rev Oncol Hematol 2004, 51:55-67.

27. Camargo MC, Goto Y, Zabaleta J, Morgan D, Correa P, Rabkin CS: Sex Hormones, Hormonal Interventions and Gastric Cancer Risk: A MetaAnalysis. Cancer Epidemiol Biomarkers Prev 2012, 21:20-38.

28. Chakrabarti I, Cockburn M, Cozen W, Wang YP, Preston-Martin S: A population-based description of glioblastoma multiforme in Los Angeles County, 1974-1999. Cancer 2005, 104:2798-2806.

29. Baldwin RT, Preston-Martin S: Epidemiology of brain tumors in childhooda review. Toxicol Appl Pharmacol 2004, 199:118-131.

30. Bax DA, Mackay A, Little SE, Carvalho D, Viana-Pereira M, Tamber N, Grigoriadis AE, Ashworth A, Reis RM, Ellison DW, Al-Sarraj S, Hargrave D, Jones C: A distinct spectrum of copy number aberrations in pediatric high-grade gliomas. Clin Cancer Res 2011, 16:3368-3377.

31. Korshunov A, Remke M, Werft W, Benner A, Ryzhova M, Witt H, Sturm D, Wittmann A, Schöttler A, Felsberg J, Reifenberger G, Rutkowski S, Scheurlen W, Kulozik AE, von Deimling A, Lichter P, Pfister SM: Adult and pediatric medulloblastomas are genetically distinct and require different algorithms for molecular risk stratification. J Clin Oncol 2011, 28:3054-3060.

32. Merchant TE, Pollack IF, Loeffler JS: Brain tumors across the age spectrum: biology, therapy, and late effects. Semin Radiat Oncol 2011, 20:58-66.

33. Smoll NR: Relative survival of childhood and adult medulloblastomas and primitive neuroectodermal tumors (PNETs). Cancer

34. Jones DT, Mulholland SA, Pearson DM, Malley DS, Openshaw SW, Lambert SR, Liu L, Backlund LM, Ichimura K, Collins VP: Adult grade II diffuse astrocytomas are genetically distinct from and more aggressive than their paediatric counterparts. Acta Neuropathol 2011, 121:753-761.

35. Parsons DW, Li M, Zhang X, Jones S, Leary RJ, Lin JC, Boca SM, Carter H, Samayoa J, Bettegowda C, Gallia GL, Jallo Gl, Binder ZA, Nikolsky Y, Hartigan J, Smith DR, Gerhard DS, Fults DW, VandenBerg S, Berger MS, Marie SK, Shinjo SM, Clara C, Phillips PC, Minturn JE, Biegel JA, Judkins AR, Resnick AC, Storm PB, Curran T, et al: The genetic landscape of the childhood cancer medulloblastoma. Science 2011, 331:435-439.

36. Northcott PA, Hielscher T, Dubuc A, Mack S, Shin D, Remke M, Al-Halabi $H_{4}$ Albrecht S, Jabado N, Eberhart CG, Grajkowska W, Weiss WA, Clifford SC, Bouffet E, Rutka JT, Korshunov A, Pfister S, Taylor MD: Pediatric and adult sonic hedgehog medulloblastomas are clinically and molecularly distinct. Acta Neuropathol 2011, 122:231-240.

37. Jha P, Suri V, Singh G, Jha P, Purkait S, Pathak P, Sharma V, Sharma MC, Suri A, Gupta D, Mahapatra AK, Sarkar C: Characterization of molecular genetic alterations in GBMs highlights a distinctive molecular profile in young adults. Diagn Mol Pathol 2011, 20:225-232.

38. Suri V, Das $P$, Pathak $P$, Jain A, Sharma MC, Borkar SA, Suri A, Gupta D, Sarkar C: Pediatric glioblastomas: a histopathological and molecular genetic study. Neuro Oncol 2009, 11:274-280.

39. Khuntia D, Brown P, Li J, Mehta MP: Whole-brain radiotherapy in the management of brain metastasis. J Clin Oncol 2006, 24:1295-1304.

40. Norden AD, Wen PY, Kesari S: Brain metastases. Curr Opin Neurol 2005, 18:654-661.

41. Klos KJ, O'Neill BP: Brain metastases. Neurologist 2004, 10:31-46.

42. U.S. Cancer Statistics Working Group: United States Cancer Statistics: 19992007 Incidence and Mortality Web-Based Report Atlanta: US Department of Health and Human Services, Centers for Disease Control and Prevention andNational Cancer Institute; 2010.

43. Assouline A, Levy A, Chargari C, Lamproglou I, Mazeron JJ, Krzisch C: Whole brain radiotherapy: prognostic factors and results of a radiation boost delivered through a conventional linear accelerator. Radiother Oncol 2011, 99:214-217.

44. Videtic GM, Reddy CA, Chao ST, Rice TW, Adelstein DJ, Barnett GH, Mekhail TM, Vogelbaum MA, Suh JH: Gender, race, and survival: a study in non-small-cell lung cancer brain metastases patients utilizing the radiation therapy oncology group recursive partitioning analysis classification. Int J Radiat Oncol Biol Phys 2009, 75:1141-1147.

45. Lagerwaard FJ, Levendag PC, Nowak PJ, Eijkenboom WM, Hanssens PE, Schmitz PI: Identification of prognostic factors in patients with brain metastases: a review of 1292 patients. Int I Radiat Oncol Biol Phys 1999, 43:795-803.

46. Chao ST, Barnett GH, Liu SW, Reuther AM, Toms SA, Vogelbaum MA, Videtic GM, Suh JH: Five-year survivors of brain metastases: a singleinstitution report of 32 patients. Int J Radiat Oncol Biol Phys 2006, 66:801-809.

47. Arrieta O, Saavedra-Perez D, Kuri R, Aviles-Salas A, Martinez L, MendozaPosada D, Castillo P, Astorga A, Guzman E, De la Garza J: Brain metastasis development and poor survival associated with carcinoembryonic antigen (CEA) level in advanced non-small cell lung cancer: a prospective analysis. BMC Cancer 2009, 9:119.

48. Sampson JH, Carter JH, Friedman AH, Seigler HF: Demographics, prognosis, and therapy in 702 patients with brain metastases from malignant melanoma. J Neurosurg 1998, 88:11-20.

49. Raizer JJ, Hwu WJ, Panageas KS, Wilton A, Baldwin DE, Bailey E, von Althann C, Lamb LA, Alvarado G, Bilsky MH, Gutin PH: Brain and leptomeningeal metastases from cutaneous melanoma: survival outcomes based on clinical features. Neuro Oncol 2008, 10:199-207.

50. Hofmann MA, Coll SH, Kuchler I, Kiecker F, Wurm R, Sterry W, Trefzer U: Prognostic factors and impact of treatment in melanoma brain metastases: better prognosis for women? Dermatology 2007, 215:10-16.

51. Gobel U, Schneider DT, Teske C, Schonberger S, Calaminus G: Brain metastases in children and adolescents with extracranial germ cell tumor - data of the MAHO/MAKEI-registry. Klin Padiatr 222:140-144.

52. Cuccia V, Galarza M: Pure pineal germinomas: analysis of gender incidence. Acta Neurochir (Wien) 2006, 148:865-871.

53. Goodwin TL, Sainani K, Fisher PG: Incidence patterns of central nervous system germ cell tumors: a SEER Study. J Pediatr Hematol Oncol 2009, 31:541-544.

54. Keene D, Johnston D, Strother D, Fryer C, Carret AS, Crooks B, Eisenstat D, Moghrabi A, Wilson B, Brossard J, Mpofu C, Odame I, Zelcer S, Silva M, Samson Y, Hand J, Bouffet E, Canadian Pediatric Brain Tumor Consortium: Epidemiological survey of central nervous system germ cell tumors in Canadian children. J Neurooncol 2007, 82:289-295.

55. Echevarria ME, Fangusaro J, Goldman S: Pediatric central nervous system germ cell tumors: a review. Oncologist 2008, 13:690-699.

56. Jennings MT, Gelman R, Hochberg F: Intracranial germ-cell tumors: natural history and pathogenesis. J Neurosurg 1985, 63:155-167.

57. Rosenblum MK, Nakazato Y, Matsutani M: CNS germ cell tumours. In WHO Classification of Tumours of the Nervous System. Edited by: Louis DN, Ohgaki H, Wiestler OD, Cavenee WK. Lyon, France: WHO Press; 2007:197-204.

58. McCarthy MM, Auger AP, Bale TL, De Vries GJ, Dunn GA, Forger NG, Murray EK, Nugent BM, Schwarz JM, Wilson ME: The epigenetics of sex differences in the brain. J Neurosci 2009, 29:12815-12823.

59. Wilson CA, Davies DC: The control of sexual differentiation of the reproductive system and brain. Reproduction 2007, 133:331-359.

60. Sanchez FJ, Vilain E: Genes and brain sex differences. Prog Brain Res 2010, 186:65-76

61. Bermejo-Alvarez P, Rizos D, Rath D, Lonergan P, Gutierrez-Adan A: Epigenetic differences between male and female bovine blastocysts produced in vitro. Physiol Genomics 2008, 32:264-272.

62. Bermejo-Alvarez P, Rizos D, Lonergan P, Gutierrez-Adan A: Transcriptional sexual dimorphism in elongating bovine embryos: implications for $\mathrm{XCI}$ and sex determination genes. Reproduction 2011, 141:801-808.

63. Bermejo-Alvarez P, Rizos D, Lonergan P, Gutierrez-Adan A: Transcriptional sexual dimorphism during preimplantation embryo development and its consequences for developmental competence and adult health and disease. Reproduction 2011, 141:563-570.

64. Eakin GS, Hadjantonakis AK: Sex-specific gene expression in preimplantation mouse embryos. Genome Biol 2006, 7:205.

65. Kobayashi S, Isotani A, Mise N, Yamamoto M, Fujihara Y, Kaseda K, Nakanishi T, Ikawa M, Hamada H, Abe K, Okabe M: Comparison of gene expression in male and female mouse blastocysts revealed imprinting of the X-linked gene, Rhox5/Pem, at preimplantation stages. Curr Biol 2006, 16:166-172. 
66. Gardner DK, Larman MG, Thouas GA: Sex-related physiology of the preimplantation embryo. Mol Hum Reprod 2010, 16:539-547.

67. Ray PF, Conaghan J, Winston RM, Handyside AH: Increased number of cells and metabolic activity in male human preimplantation embryos following in vitro fertilization. J Reprod Fertil 1995, 104:165-171.

68. Mittwoch $U$ : The elusive action of sex-determining genes: mitochondria to the rescue? J Theor Biol 2004, 228:359-365.

69. Cairns RA, Harris IS, Mak TW: Regulation of cancer cell metabolism. Nat Rev Cancer 2011, 11:85-95.

70. Koppenol WH, Bounds PL, Dang CV: Otto Warburg's contributions to current concepts of cancer metabolism. Nat Rev Cancer 2011, 11:325-337.

71. Ordys BB, Launay S, Deighton RF, McCulloch J, Whittle IR: The role of mitochondria in glioma pathophysiology. Mol Neurobiol 2010, 42:64-75.

72. Hanahan D, Weinberg RA: Hallmarks of cancer: the next generation. Cell 2011, 144:646-674

73. Hirschhaeuser F, Sattler UG, Mueller-Klieser W: Lactate: a metabolic key player in cancer. Cancer Res 71:6921-6925.

74. Tatevossian RG, Lawson AR, Forshew T, Hindley GF, Ellison DW, Sheer D: MAPK pathway activation and the origins of pediatric low-grade astrocytomas. J Cell Physiol 2011, 222:509-514.

75. Ehrlichman LK, Ford JW, Roelofs KJ, Tedeschi-Filho W, Futchko JS, Ramacciotti E, Eliason JL, Henke PK, Upchurch GR Jr: Gender-dependent differential phosphorylation in the ERK signaling pathway is associated with increased MMP2 activity in rat aortic smooth muscle cells. J Surg Res 2010, 160:18-24.

76. Gresack JE, Schafe GE, Orr PT, Frick KM: Sex differences in contextual fear conditioning are associated with differential ventral hippocampal extracellular signal-regulated kinase activation. Neuroscience 2009, 159:451-467.

77. Barabas K, Szego EM, Kaszas A, Nagy GM, Juhasz GD, Abraham IM: Sex differences in oestrogen-induced p44/42 MAPK phosphorylation in the mouse brain in vivo. J Neuroendocrinol 2006, 18:621-628.

78. Azcoitia I, Santos-Galindo M, Arevalo MA, Garcia-Segura LM: Role of astroglia in the neuroplastic and neuroprotective actions of estradiol. Eur J Neurosci 2010, 32:1995-2002.

79. Zhang L, Li B, Zhao W, Chang YH, Ma W, Dragan M, Barker JL, Hu Q, Rubinow DR: Sex-related differences in MAPKs activation in rat astrocytes: effects of estrogen on cell death. Brain Res Mol Brain Res 2002, 103:1-11.

80. Liu M, Hurn PD, Roselli CE, Alkayed NJ: Role of P450 aromatase in sexspecific astrocytic cell death. J Cereb Blood Flow Metab 2007, 27:135-141.

81. Barone TA, Gorski JW, Greenberg SJ, Plunkett RJ: Estrogen increases survival in an orthotopic model of glioblastoma. J Neurooncol 2009, 95:37-48.

82. Shaywitz AJ, Greenberg ME: CREB: a stimulus-induced transcription factor activated by a diverse array of extracellular signals. Annu Rev Biochem 1999, 68:821-861.

83. Wan Y, Yang M, Kolattukudy S, Stark GR, Lu T: Activation of CAMPresponsive-element-binding protein by $\mathrm{PI} 3$ kinase and p38 MAPK is essential for elevated expression of transforming growth factor beta2 in cancer cells. J Interferon Cytokine Res 2010, 30:677-681.

84. Paget S: The distribution of secondary growths in cancer of the breast. 1889. Cancer Metastasis Rev 1989, 8:98-101.

85. Hart IR, Fidler IJ: Role of organ selectivity in the determination of metastatic patterns of B16 melanoma. Cancer Res 1980, 40:2281-2287.

86. Fidler IJ: The role of the organ microenvironment in brain metastasis. Semin Cancer Biol 2011, 21:107-112.

87. Solnica-Krezel $\mathrm{L}$ : Conserved patterns of cell movements during vertebrate gastrulation. Curr Biol 2005, 15:R213-228.

88. Micalizzi DS, Ford HL: Epithelial-mesenchymal transition in development and cancer. Future Oncol 2009, 5:1129-1143.

89. DeNardo DG, Johansson M, Coussens LM: Immune cells as mediators of solid tumor metastasis. Cancer Metastasis Rev 2008, 27:11-18.

90. Chambers AF, Naumov GN, Varghese HJ, Nadkarni KV, MacDonald IC, Groom AC: Critical steps in hematogenous metastasis: an overview. Surg Oncol Clin N Am 2001, 10:243-255, vii.

91. Zhang C, Zhang F, Tsan R, Fidler IJ: Transforming growth factor-beta2 is a molecular determinant for site-specific melanoma metastasis in the brain. Cancer Res 2009, 69:828-835.

92. Soltermann A, Tischler V, Arbogast S, Braun J, Probst-Hensch N, Weder W, Moch $H$, Kristiansen $G$ : Prognostic significance of epithelial-mesenchymal and mesenchymal-epithelial transition protein expression in non-small cell lung cancer. Clin Cancer Res 2008, 14:7430-7437.

93. Cerwenka A, Lanier LL: Natural killer cells, viruses and cancer. Nat Rev Immunol 2001, 1:41-49.

94. Page GG, Fennelly AM, Littleton-Kearney MT, Ben-Eliyahu S: Male-female differences in the impact of beta-adrenoceptor stimulation on resistance to experimental metastasis: exploring the effects of age and gonadal hormone involvement. J Neuroimmunol 2008, 193:113-119.

95. Singh S, Swarnkar S, Goswami P, Nath C: Astrocytes and microglia: responses to neuropathological conditions. Int J Neurosci 121:589-597.

96. Seike T, Fujita K, Yamakawa Y, Kido MA, Takiguchi S, Teramoto N, Iguchi $H_{\text {, }}$ Noda M: Interaction between lung cancer cells and astrocytes via specific inflammatory cytokines in the microenvironment of brain metastasis. Clin Exp Metastasis 28:13-25.

97. Kim SJ, Kim JS, Park ES, Lee JS, Lin Q, Langley RR, Maya M, He J, Kim SW, Weihua Z, Balasubramanian K, Fan D, Mills GB, Hung MC, Fidler IJ: Astrocytes upregulate survival genes in tumor cells and induce protection from chemotherapy. Neoplasia 2011, 13:286-298.

98. Giavazzi R, Garofalo A, Bani MR, Abbate M, Ghezzi P, Boraschi D, Mantovani A, Dejana E: Interleukin 1-induced augmentation of experimental metastases from a human melanoma in nude mice. Cancer Res 1990, 50:4771-4775.

99. Vidal-Vanaclocha F, Amezaga C, Asumendi A, Kaplanski G, Dinarello CA: Interleukin-1 receptor blockade reduces the number and size of murine B16 melanoma hepatic metastases. Cancer Res 1994, 54:2667-2672.

100. Vidal-Vanaclocha F, Alvarez A, Asumendi A, Urcelay B, Tonino P, Dinarello CA: Interleukin 1 (IL-1)-dependent melanoma hepatic metastasis in vivo; increased endothelial adherence by IL-1-induced mannose receptors and growth factor production in vitro. $J$ Nat/ Cancer Inst 1996, 88:198-205.

101. Rakoff-Nahoum S, Medzhitov R: Regulation of spontaneous intestinal tumorigenesis through the adaptor protein MyD88. Science 2007 317:124-127.

102. Naugler WE, Sakurai T, Kim S, Maeda S, Kim K, Elsharkawy AM, Karin M Gender disparity in liver cancer due to sex differences in MyD88dependent IL-6 production. Science 2007, 317:121-124.

103. Santos-Galindo M, Acaz-Fonseca E, Bellini MJ, Garcia-Segura LM: Sex differences in the inflammatory response of primary astrocytes to lipopolysaccharide. Biol Sex Differ 2:7.

104. Goodrich LV, Milenkovic L, Higgins KM, Scott MP: Altered neural cell fates and medulloblastoma in mouse patched mutants. Science 1997, 277:1109-1113.

105. Wetmore $C$, Eberhart DE, Curran T: The normal patched allele is expressed in medulloblastomas from mice with heterozygous germ-line mutation of patched. Cancer Res 2000, 60:2239-2246.

106. Mancuso M, Leonardi S, Ceccarelli M, Pasquali E, De Stefano I, Prisco MG, Rebessi S, Tanori M, Scambia G, Di Majo V, Pazzaglia S, Saran A, Gallo D: Protective role of 17 beta-estradiol on medulloblastoma development in Patched 1 heterozygous mice. Int J Cancer 127:2749-2757.

107. Northcott PA, Korshunov A, Witt H, Hielscher T, Eberhart CG, Mack S, Bouffet E, Clifford SC, Hawkins CE, French P, Rutka JT, Pfister S, Taylor MD: Medulloblastoma comprises four distinct molecular variants. J Clin Oncol 29:1408-1414.

108. Lin Q, Balasubramanian K, Fan D, Kim SJ, Guo L, Wang H, Bar-Eli M, Aldape KD, Fidler IJ: Reactive astrocytes protect melanoma cells from chemotherapy by sequestering intracellular calcium through gap junction communication channels. Neoplasia 2010, 12:748-754.

109. Weil MD, Lamborn K, Edwards MS, Wara WM: Influence of a child's sex on medulloblastoma outcome. JAMA 1998, 279:1474-1476.

110. Prados MD, Wara W, Edwards MS, Ater J, Rabbit J, Lamborn K, Davis R, Levin VA: Treatment of high-risk medulloblastoma and other primitive neuroectodermal tumors with reduced dose craniospinal radiation therapy and multi-agent nitrosourea-based chemotherapy. Pediatr Neurosurg 1996, 25:174-181.

111. Claus EB, Black PM: Survival rates and patterns of care for patients diagnosed with supratentorial low-grade gliomas: data from the SEER program, 1973-2001. Cancer 2006, 106:1358-1363.

112. Caloglu M, Yurut-Caloglu V, Karagol H, Bayir-Angin G, Turan FN, Uzal C: Prognostic factors other than the performance status and age for glioblastoma multiforme: a single-institution experience. J Buon 2009, 14:211-218. 
113. Shinojima N, Kochi M, Hamada J, Nakamura H, Yano S, Makino K, Tsuiki H, Tada K, Kuratsu J, Ishimaru Y, Ushio Y: The influence of sex and the presence of giant cells on postoperative long-term survival in adult patients with supratentorial glioblastoma multiforme. J Neurosurg 2004, 101:219-226.

doi:10.1186/2042-6410-3-3

Cite this article as: Sun et al:: Why does Jack, and not Jill, break his crown? Sex disparity in brain tumors. Biology of Sex Differences 2012 3:3.

Submit your next manuscript to BioMed Central and take full advantage of:

- Convenient online submission

- Thorough peer review

- No space constraints or color figure charges

- Immediate publication on acceptance

- Inclusion in PubMed, CAS, Scopus and Google Scholar

- Research which is freely available for redistribution 